\title{
Effects of Dietary Supplementation of Fermented Rice Bran (FRB) or Fermented Broken Rice (FBR) on Laying Performance, Egg Quality, Blood Parameter, and Cholesterol in Egg Yolk of Hy-Line Brown Laying Hens
}

\author{
Chan Ho Kim, Seong Bok Park, Jin Joo Jeon, Hyun Soo Kim, Sang Ho Kim, Eui Chul Hong and Hwan Ku Kang ${ }^{\dagger}$ \\ Poultry Research Institute, Rural Development Administration, National Institute of Animal Science, Pyeongchang 25342, Republic of Korea
}

\begin{abstract}
This experiment was aimed at investigating the effects of dietary supplementation with fermented rice bran (FRB) or fermented broken rice (FBR) on egg-laying performance, egg quality, blood parameters, and cholesterol level in egg yolk of Hy-Line Brown egg-laying hens. Altogether, 144 Hy-Line Brown egg-laying hens (32-week-old) were randomly allocated to one of 4 dietary treatment groups, with 4 replicates per treatment. Of them, 3 treatments diets were prepared by supplementing the basal diet with $0.1 \%$ probiotics (PRO), $1 \%$ fermented rice bran (FRB), or $1 \%$ fermented broken rice (FBR) at the expense of corn. Hen-day egg production was higher $(P<0.05)$ in PRO and FRB treatment groups than in the basal treatment groups. However, feed intake, egg weight, egg mass, and feed conversion ratio did not differ among the treatment groups. Additionally, supplementation with FRB or FBR did not affect eggshell strength, eggshell thickness, egg yolk color, and Haugh unit during the feeding trial. There was no significant difference in leukocyte count. Total cholesterol level was lower $(P<0.05)$ in the FRB treatment group than in the basal treatment groups. Asparate aminotransferase, alanine transferase, glucose, and albumin levels were unaffected by dietary supplementation with FRB or FBR. Egg yolk cholesterol level was lower $(P<0.05)$ in the FRB and FBR treatment groups than in the basal treatment groups. In conclusion, dietary supplementation with FRB or FBR improved egg-laying performance, and reduced the levels of total serum cholesterol and cholesterol in egg yolk of Hy-Line Brown egg-laying hens.
\end{abstract}

(Key words: Hy-Line Brown laying hens, laying performance, fermented rice bran, fermented broken rice, total cholesterol)

\section{INTRODUCTION}

Rice bran is a major cereal by-product, which is widely used in rice-producing countries as a feed ingredient in layer diets. It contains considerable amounts of fat, protein, metabolizable energy and a good source of B-group vitamins (Kratzer et al., 1974; Warren and Farrell, 1990; Rezaei, 2006). Broken rice kernels have normally only half of the value of whole or head rice. The head rice yield, i.e., the weight percentage of whole kernals remaining after milling is one of the most important physical characteristics that determines rice quality (Van Dalen, 2004). Among these, broken rice separated out after the polishing stage has the same chemical composition as polished rice; even though the quantities available are not very high, this by-product is a palatable, energy-rich and easily utilized feed. Another characteristic of this by-product is that it has low-protein content. Its protein is richer in lysine than that of other major cereals (De Marco et al., 2014). Therefore, it is a common feed supplement in animal production, including poultry (Mu et al., 2011). Previous research on the supplementation of rice bran to broiler chicken fed has shown to improve growth performance (Maust et al., 1972; Zombade et al., 1982). In addition, studies on the usefulness of fermented rice bran (FRB) and fermented broken rice (FBR) for improving growth are scarce. However, the response of animals to feed containing FRB or FBR with respect to laying performance, blood parameters, and cholesterol in egg yolk has yet to be described. The fermentation of materials with microbial inoculums has been widely adopted to develop novel functional ingredients because this process may promote their functional quality such as antioxidant (Lee et al., 2008; Dini, 2010; Wang et al., 2011; Cao et al., 2012; Kim et al., 2012). This study aimed to determine whether the dietary supplementation of FRB or FBR to laying hens feed affects laying performance, egg quality, blood parameter, and cholesterol in egg yolk. Such information is expected to confirm the utility

${ }^{\dagger}$ To whom correspondence should be addressed : magic100@korea.kr 
of FRB or FBR as a dietary supplement for Hy-Line Brown laying hens.

\section{MATERIALS AND METHODS}

The protocol for this experiment was reviewed and approved by the Institute Animal Care and Welfare Committee of the National Institute of Animal Science, Rural Development Administration, Republic of Korea.

\section{Preparation of Lactobacillus-fermented Rice Bran or Broken Rice}

Rice bran and broken rice harvested in 2015 were obtained from a rice processing complex (Seonghwan-eup, South Korea). Strains of microbes-Lactobacillus plantarum KCTC 1048 (Korean Collection for Type Culture, Daejeon, Korea) was obtained and used to ferment rice bran in this experiment. A $2-\mathrm{mL}$ aliquot of Lactobacillus strain with $10^{6} \mathrm{cfu} / \mathrm{mL}$ viable counts, was cultured in medium (1 L) containing $10 \mathrm{~g}$ de Man, Rogosa, and Sharpe broth (Difco Laboratories, Francisco Soria Melguizo S. A., Madrid, Spain) and $1 \mathrm{~L}$ of distilled water. The mixture was then incubated at $36^{\circ} \mathrm{C}$ for $24 \mathrm{~h}$. For fermentation, $4 \mathrm{~kg}$ of dried rice bran was inoculated with $5 \mathrm{~L}$ of prepared Lactobacillus inoculums in a fermentation vessel, and incubated at $36^{\circ} \mathrm{C}$ with periodic mixing for $24 \mathrm{~h}$. At the end of the fermentation, fermented rice bran was dried at 60 ${ }^{\circ} \mathrm{C}$ to contain approximately $76 \sim 77 \%$ dry matter (DM), and was subsequently used for the feeding trial. The final concentrations of Lactobacillus in the probiotic products were approximately $10^{8} \mathrm{cfu} / \mathrm{g}$ fermented product.

The nutrient compositions of FRB and FBR were analyzed in duplicate for DM, crude ash, crude protein, and crude fiber (AOAC, 1990). The results are presented in Table 1.

\section{Birds and Experimental Design}

A total 144, 32-week old Hy-Line Brown laying hens were randomly allotted to 1 of 4 dietary treatments. Each treatment had 4 replicated with 3 cages and 3 hens per cage $(36 \mathrm{~cm} \times$ $40 \mathrm{~cm} \times 42 \mathrm{~cm}=$ width $\times$ length $\times$ height) in each replication. A commercial type basal diet was formulated to meet or exceed nutrient recommendations of the National Research Council (1994) for laying hens (Table 2). Three treatments
Table 1. Analyzed compostion of fermented rice bran (FRB) and fermented broken rice (FBR) (DM-basis)

\begin{tabular}{crc}
\hline \hline Composition $(\mathrm{g} / \mathrm{kg})$ & $\mathrm{FRB}^{1}$ & $\mathrm{FBR}^{2}$ \\
\hline DM & 774.0 & 769.5 \\
Crude ash & 70.0 & 2.4 \\
Crude protein & 136.0 & 56.6 \\
Crude fiber & 71.0 & 3.0 \\
\hline
\end{tabular}

\footnotetext{
${ }^{1}$ Lactobacillus-fermented rice bran.
}

${ }^{2}$ Lactobacillus-fermented broken rice.

diets were prepared by supplementing $0.1 \%$ probiotics (PRO) that contained a mixture of Lactobacillus reuteri, $1 \%$ fermented rice bran (FRB), or $1 \%$ fermented broken rice (FBR) to the basal diet at the expense of corn. The experimental period was 8 weeks. During the experiment, hens were provided with feed and water ad libitum and were exposed to $16 \mathrm{~h}: 8$ $\mathrm{h}$ light: dark lighting schedule. The temperature and humidity of the laying house was maintained at $18 \pm 3^{\circ} \mathrm{C}$ and $65 \sim 70 \%$, respectively, during the experiment.

\section{Laying Performance}

Hen-day egg production rate, oviposition rate, broken egg production rate and egg weight were recorded daily, whereas feed intake and the feed conversion ratio were recorded weekly. Egg mass was calculated as per Hayat et al. (2009).

Egg mass $=$ Weekly number of eggs in a replicate $\times$ Average egg weight

\section{Determination of Egg Quality Parameter}

Ten eggs per replicate were randomly collected at the end of every week. Eggshell strength, eggshell thickness, egg yolk colour, and Haugh units (HU) were measured. Eggshell strength was measured by the Texture Systems Compression Test Cell (model T2100C, Food Technology Co., Ltd., Rock- ville, MD, USA) and expressed as units of compression force exposed to units of eggshell surface area $\left(\mathrm{kg} / \mathrm{cm}^{2}\right)$. Egg shell thickness is defined as the mean value of measurements at 3 different locations on the egg (air cell, equator, and sharp end) and was measured with a dial pipe gauge (model 7360, Mitutoyo Co. Ltd., Kawasaki, Japan) and calculated using the 
Table 2. Composition and nutrient content of experimental diet (as-fed basis)

\begin{tabular}{|c|c|c|c|c|c|}
\hline & Item & Basal & PRO & FRB & FBR \\
\hline \multirow{14}{*}{$\begin{array}{l}\text { Ingredients } \\
(\mathrm{g} / \mathrm{kg})\end{array}$} & Corn & 595.3 & 594.3 & 585.3 & 585.3 \\
\hline & Soybean meal & 224.9 & 224.9 & 224.9 & 224.9 \\
\hline & Wheat & 40.0 & 40.0 & 40.0 & 40.0 \\
\hline & Limestone & 98.5 & 98.5 & 98.5 & 98.5 \\
\hline & Tallow & 14.0 & 14.0 & 14.0 & 14.0 \\
\hline & Mono dicalcium phosphate & 19.0 & 19.0 & 19.0 & 19.0 \\
\hline & DL-methionine (99\%) & 2.4 & 2.4 & 2.4 & 2.4 \\
\hline & Lysin- $\mathrm{HCl}(78 \%)$ & 1.4 & 1.4 & 1.4 & 1.4 \\
\hline & Salt & 2.5 & 2.5 & 2.5 & 2.5 \\
\hline & Vitamin-mineral premix ${ }^{1}$ & 2.0 & 2.0 & 2.0 & 2.0 \\
\hline & Probitocis (PRO) & - & 1.0 & - & - \\
\hline & Lactobacillus fermented rice bran (FRB) & - & - & 10.0 & - \\
\hline & Lactobacillus fermented half crushed rice (FBR) & - & - & - & 10.0 \\
\hline & Total & $1,000.0$ & $1,000.0$ & $1,000.0$ & $1,000.0$ \\
\hline \multirow{6}{*}{$\begin{array}{c}\text { Energy and } \\
\text { nutrient content }{ }^{2}\end{array}$} & $\mathrm{ME}_{\mathrm{n}}(\mathrm{MJ} / \mathrm{kg})$ & 11.66 & 11.66 & 11.66 & 11.66 \\
\hline & Crude protein $(\mathrm{g} / \mathrm{kg})$ & 164.2 & 164.2 & 164.2 & 164.2 \\
\hline & Calcium $(\mathrm{g} / \mathrm{kg})$ & 39.8 & 39.8 & 39.8 & 39.8 \\
\hline & Available P (g/kg) & 7.2 & 7.2 & 7.2 & 7.2 \\
\hline & Lysine $(\mathrm{g} / \mathrm{kg})$ & 9.5 & 9.5 & 9.5 & 9.5 \\
\hline & Methionine + cysteine $(\mathrm{g} / \mathrm{kg})$ & 7.8 & 7.8 & 7.8 & 7.8 \\
\hline
\end{tabular}

${ }^{1}$ Provided per kilogram of the complete diet: vitamin A (from vitamin A acetate), 12,500 IU; vitamin $\mathrm{D}_{3}$, 2,500 IU; vitamin E (from DL- $\alpha$-tocopheryl acetate), $20 \mathrm{IU}$; vitamin $\mathrm{K}_{3}, 2 \mathrm{mg}$; vitamin $\mathrm{B}_{2}, 5 \mathrm{mg}$; vitamin $\mathrm{B}_{6}, 3 \mathrm{mg}$; vitamin $\mathrm{B}_{12}, 18 \mu \mathrm{g}$; calcium pantothenate, 8 $\mathrm{mg}$; folic acid, $1 \mathrm{mg}$; biotin, $50 \mu \mathrm{g}$; niacin, $24 \mathrm{mg}$; $\mathrm{Zn}$ (as $\mathrm{ZnO}), 60 \mathrm{mg}$; $\mathrm{Mn}$ (as $\mathrm{MnSO}_{2} \cdot \mathrm{H}_{2} \mathrm{O}$ ), $50 \mathrm{mg} ; \mathrm{Fe}\left(\right.$ as $\mathrm{FeSO} 4 \cdot 7 \mathrm{H}_{2} \mathrm{O}$ ), 50 mg; $\mathrm{Cu}$ (as $\mathrm{CuSO}_{4} \cdot 5 \mathrm{H}_{2} \mathrm{O}$ ), $6 \mathrm{mg}$; $\mathrm{Co}\left(\right.$ as $\left.\mathrm{CoCO}_{3}\right), 250 \mu \mathrm{g}$; I [as $\mathrm{Ca}\left(\mathrm{IO}_{3}\right)_{2} \cdot \mathrm{H}_{2} \mathrm{O}$ ], $1 \mathrm{mg}$; Se (as $\left.\mathrm{Na}_{2} \mathrm{SeO}_{3}\right), 150 \mu \mathrm{g}$.

${ }^{2}$ Nutrient contents in all diet were calculated were analyzed.

following equation:

Eggshell thickness $=($ Sharp point thickness +

Equator point thickness + Air cell thickness) $/ 3$

Egg yolk colour was evaluated by the Roche Yolk Color Fan (Hoffman-La Roche Ltd., Basel, Switzerland; 15 = dark orange; 1 = light pale). Hough unit values were calculated using a micrometer (model S-8400, Ames, Walthman, MA, USA) with the following equation described by Eisen et al. (1962):

$$
\mathrm{HU}=100 \log \left(H-1.7 \mathrm{~W}^{0.37}+7.6\right)
$$

where $W$ is egg weight, and $H$ is albumen height.

\section{Sample Collection}

At the end of the 8 week feeding trial, one bird with a BW close to the pen BW (i.e., 8 birds per treatment) was selected and killed by cervical dislocation. Immediately after death, a $5 \mathrm{~mL}$ blood sample was collected from the jugular vein of each bird using EDTA vacuum tubes (Becton Dickinson, Franklin Lakes, NJ), which were then stored on ice and subjected to immediate haematological analysis. Leukocytes: white blood cells, heterophils, lymphocytes, monocytes, eosinophils, and basophils were quantified using Hemavet Multispecies Hema- 
tology systems (Drew Scientific Inc., Oxford, CT). The H:L ratios were determined by dividing the number of heterophils by that of lymphocytes. Serum samples obtained by centrifuging the samples for $20 \mathrm{~min}$ at $25,000 \times \mathrm{g}$ and $4^{\circ} \mathrm{C}$, were stored at $-15^{\circ} \mathrm{C}$. Total cholesterol, triglyceride, aspirate aminotransperase (AST), alanine aminotransperase (ALT), and calcium in the serum were quantified using an ADVIA 1650 chemistry system (Bayer Diagnostic, Putraux, France).

\section{Determination of Egg Yolk Cholesterol Level}

Egg yolk cholesterol level was measured by using 40 eggs (10 eggs from each treatment) collected in the last week of the experiment. A sample of $2 \sim 3$ eggs from each replicate was used for cholesterol quantification. Egg yolks were completely separated from the albumen, adhering white and chalazae; then weighted, pooled and mixed. The cholesterol content of egg yolk was determined following colorimetric method based on Liebermann-Burchard color reaction as described by Huang et al. (1961). Briefly, chloroform:methanol (2:1 v/v) solvent was used to extract total lipids from egg yolk. The harvested extracts, which contain free cholesterol and cholesterol esters, were allowed to react with acetic anhydride and concentrated sulfuric acid, resulting in the formation of a bluegreen com- plex. Egg yolk cholesterol content was quantified by comparing the color absorbance at $550 \mathrm{~nm}$ resulting from the Libermann-Buchard reactions in egg yolk lipid extracts with cholesterol standards (Cholesterol reagent, Gainland Chemical Company, UK). All the reading were blanked against a chloroform: methanol.

\section{Statistical Analysis}

All data were analyzed by one-way ANOVA as a completely randomized design using the PROC GLM procedure (SAS Institute Inc., Cary, NC). Each replicate was considered an experimental unit for the analysis of laying performance, blood parameter, and egg cholesterol. Outlier data were examined according to the method of Steel et al. (1997) using the UNIVARIATE procedure of SAS; however, no outliers were identified. The LSMEANS square means were separated using Fisher's LSD (Ott and Longnecker, 2009) and significance was set at $P \leq 0.05$ and $0.05 \leq P \leq 0.10$.

\section{RESULTS AND DISCUSSION}

Hen-day egg production was greater $(P<0.05)$ for PRO and FRB treatment groups than for the basal treatments. However, feed intake, egg weight, egg mass and feed conversion ratio did not differed among the treatments. Dietary supplementation of fermented rice bran has been reported improve BW gain and feed efficiency in broilers and pigs (Chu et al., 2011; Kang et al., 2015; Supriyati et al., 2015). The positive effects of fermented rice bran on growth performance of broiler chicken may be due to its high concentrations of protein, vitamin, minerals, complex carbohydrates, phytonutrients, phospholipids, essential fatty acids and more than 120 antioxidants (Saunders, 1985; Warren and Farrell, 1990; Ryan et al., 2011). To our knowledge, however, there have been no products of rice bran or half crushed rice on laying performance of birds, and therefore, it is difficult to compare previous data with those determined in this experiment. It is suggested, however, that fermentation processes of plant materials are able to elevate the efficacy of their antioxidant and antiinflammatory properties to a level greater than that in the raw materials (Lee et al., 2008; Wang et al., 2011; Kim et al., 2012). In addition, fermented products were more palatable compared to the original materials as fermentation could produce preferred water soluble vitamin such as $B_{1}, B_{2}$ and $B_{12}$, and minerals (Kubad et al., 1997). This maybe also the reason why inclusion of relatively small amounts $(10 \mathrm{~g} / \mathrm{kg})$ of FRB or FBR indiets showed significant positive effects on laying performance of birds in this experiment. Lactobacillus spp. have been widely appreciated as potential probiotic bacteria and dietary supplementation of Lactobacillus spp. have been reported to improve growth performance of birds (Panda et al., 2006). There is also the implication that dead or inactive probiotic bacteria may improve performance and the health status of animals, possibly via similar mechanisms operating in animals fed viable probiotic bacteria (Wagner et al., 2000; Huang et al., 2004).

However, the supplementation of FRB or FBR did not have an effect on eggshell strength, eggshell thickness, egg yolk color, and HU during the feeding trial (Table 4). The lacking adequate data on the influence of supplementation with FRB 
Table 3. Laying performance of laying hens fed the diet containing probiotics, fermented rice bran and fermented broken rice ${ }^{1}$

\begin{tabular}{|c|c|c|c|c|c|c|c|}
\hline & \multirow{2}{*}{ Items } & \multicolumn{4}{|c|}{ Dietary treatments ${ }^{2}$} & \multirow{2}{*}{$\mathrm{SEM}^{3}$} & \multirow{2}{*}{$p$-value } \\
\hline & & Basal & PRO & FRB & FBR & & \\
\hline \multirow{5}{*}{$\begin{array}{c}\text { Laying } \\
\text { performance }\end{array}$} & Hen-day egg production (\%) & $85.3^{\mathrm{b}}$ & $87.1^{\mathrm{a}}$ & $86.8^{\mathrm{a}}$ & $86.3^{\mathrm{ab}}$ & 0.68 & 0.04 \\
\hline & Feed intake $(\mathrm{g})$ & 122.9 & 122.3 & 125.2 & 124.2 & 1.47 & 0.25 \\
\hline & Egg weight $(\mathrm{g})$ & 63.2 & 62.7 & 62.4 & 62.9 & 0.60 & 0.32 \\
\hline & Egg mass & 53.9 & 54.6 & 54.2 & 54.3 & 0.92 & 0.12 \\
\hline & Feed conversion ratio & 2.28 & 2.24 & 2.31 & 2.29 & 0.05 & 0.18 \\
\hline
\end{tabular}

a,b Values in a row with no common superscripts letter are significantly different $(P<0.05)$.

${ }^{1}$ Data are least squares means of 4 observations per treatments.

${ }^{2}$ Basal = basal diet; PRO $=$ basal diet $+1 \mathrm{~g} / \mathrm{kg}$ probiotics; FRB $=$ basal diet $+10 \mathrm{~g} / \mathrm{kg}$ Lactobacillus-fermented rice bran; FBR $=$ basal diet $+10 \mathrm{~g} / \mathrm{kg}$ Lactobacillus-fermented broken rice.

3 Pooled standard error of the means.

Table 4. Egg quality of laying hens fed the diet containing probiotics, fermented rice bran and fermented broken rice ${ }^{1}$

\begin{tabular}{|c|c|c|c|c|c|c|c|}
\hline & \multirow{2}{*}{ Items } & \multicolumn{4}{|c|}{ Dietary treatments ${ }^{2}$} & \multirow{2}{*}{$\mathrm{SEM}^{3}$} & \multirow{2}{*}{$p$-value } \\
\hline & & Basal & PRO & FRB & FBR & & \\
\hline \multirow{4}{*}{ Egg quality } & Eggshell strength $\left(\mathrm{kg} / \mathrm{cm}^{2}\right)$ & 3.94 & 3.42 & 3.80 & 3.92 & 0.28 & 0.28 \\
\hline & Eggshell thickness $(\mu \mathrm{m})$ & 408.60 & 401.00 & 401.30 & 400.00 & 8.48 & 0.35 \\
\hline & Egg yolk color & 7.56 & 7.97 & 7.80 & 7.78 & 0.28 & 0.13 \\
\hline & Haugh unit & 86.90 & 91.8 & 89.90 & 85.50 & 3.03 & 0.29 \\
\hline
\end{tabular}

${ }^{1}$ Data are least squares means of 4 observations per treatments.

${ }^{2}$ Basal = basal diet; PRO = basal diet $+1 \mathrm{~g} / \mathrm{kg}$ probiotics; FRB $=$ basal diet $+10 \mathrm{~g} / \mathrm{kg}$ Lactobacillus-fermented rice bran; FBR $=$ basal diet $+10 \mathrm{~g} / \mathrm{kg}$ Lactobacillus-fermented broken rice.

3 Pooled standard error of the means.

or FBR to laying hens feed on egg quality of poultry requires further research.

Table 5 presents the concentrations of leukocytes in the whole blood. There were no significant differences in the level of leukocyte. Blood parameters are good indicators of physiological, pathological and nutritional status of an animal and changes in hematological parameters have the potential of being used to elucidate the impact of nutritional factors and additives supplied in diet on any living creature. For example, leukocytes are known increase sharply when infection occurs, as they are one of the first lines of defence of the body (Ganong, 1999; Alzawqari et al., 2011; Masoudi et al., 2011). Leukocyte counts also have been used as a measure of immune function in birds (Johnson and Zuk, 1998). Many factors such as exposure to various microbes and che- micals can cause changes in both granulocytic white blood cells (Lucas and Jamroz, 1961). The lack of adequate data on the influence of dietary supplementation of FRB or FBR of laying hens in altering blood parameters in poultry requires further research.

Total cholesterol was less $(P<0.05)$ for FRB treatment group than for the basal treatments. AST, ALT, glucose, and albumin were not affected by supplementation of FRB or FCR in diets. The supplemental fermented rice bran diets decreased the concentrations of total cholesterol in this experiment. This is in contrast with previous studies. Chu et al. (2011) and Kim et al. (2006) reported that an addition of fermented materials to the feed decreased total cholesterol in pigs. Kitawaki et al. (2009) reported that Lacobacillus spp. fermented soymilk and soy yogurt decreased the concentration of plasma 
Table 5. Blood parameter of laying hens fed the diet containing probiotics, fermented rice bran and fermented broken rice ${ }^{1}$

\begin{tabular}{|c|c|c|c|c|c|c|c|}
\hline & \multirow{2}{*}{ Items } & \multicolumn{4}{|c|}{ Dietary treatments ${ }^{2}$} & \multirow{2}{*}{$\mathrm{SEM}^{3}$} & \multirow{2}{*}{$p$-value } \\
\hline & & Basal & PRO & FRB & FBR & & \\
\hline \multirow{6}{*}{$\begin{array}{c}\text { Leukocytes } \\
(\mathrm{K} / \mu \mathrm{L})\end{array}$} & White blood cells (WBC) & 6.83 & 11.48 & 12.85 & 6.05 & 1.85 & 0.65 \\
\hline & Heterophils (HE) & 0.62 & 1.40 & 1.20 & 0.83 & 0.59 & 0.79 \\
\hline & Lymphocytes (LY) & 5.62 & 8.97 & 7.06 & 5.16 & 0.85 & 0.85 \\
\hline & Monocytes (MO) & 0.55 & 1.01 & 1.29 & 0.75 & 0.23 & 0.69 \\
\hline & Eosinophils (EO) & 0.05 & 0.08 & 0.04 & 0.03 & 0.05 & 0.36 \\
\hline & Basophils (BA) & 0.01 & 0.01 & 0.03 & 0.01 & 0.85 & 0.35 \\
\hline
\end{tabular}

${ }^{1}$ Data are least squares means of 4 observations per treatments.

${ }^{2}$ Basal = basal diet; PRO = basal diet $+1 \mathrm{~g} / \mathrm{kg}$ probiotics; FRB $=$ basal diet $+10 \mathrm{~g} / \mathrm{kg}$ Lactobacillus-fermented rice bran; FBR $=$ basal diet $+10 \mathrm{~g} / \mathrm{kg}$ Lactobacillus-fermented broken rice.

3 Pooled standard error of the means.

Table 6. Blood biochemistry of laying hens fed the diet containing probiotics, fermented rice bran and fermented broken rice ${ }^{1}$

\begin{tabular}{|c|c|c|c|c|c|c|}
\hline \multirow{2}{*}{ Items } & \multicolumn{4}{|c|}{ Dietary treatments ${ }^{2}$} & \multirow{2}{*}{$\mathrm{SEM}^{3}$} & \multirow{2}{*}{$p$-value } \\
\hline & Basal & PRO & FRB & FBR & & \\
\hline Total cholesterol $(\mathrm{mg} / \mathrm{dL})$ & $128.2^{\mathrm{x}}$ & $113.4^{\mathrm{xy}}$ & $95.8^{\mathrm{y}}$ & $112.8^{\mathrm{xy}}$ & 8.50 & 0.04 \\
\hline Triglyceride (mg/dL) & $1,126.2$ & 1011.3 & $1,165.6$ & $1,198.3$ & 10.22 & 0.28 \\
\hline Glucose (mg/dL) & 189.7 & 191.6 & 191.0 & 191.1 & 6.89 & 0.32 \\
\hline Total protein $(\mathrm{mg} / \mathrm{dL})$ & 6.06 & 5.61 & 5.42 & 5.86 & 0.63 & 0.45 \\
\hline AST (U/L) & 187.5 & 176.4 & 188.3 & 169.1 & 12.69 & 0.43 \\
\hline $\operatorname{ALT}(\mathrm{U} / \mathrm{L})$ & 1.65 & 1.38 & 2.50 & 1.83 & 0.89 & 0.39 \\
\hline
\end{tabular}

${ }^{1}$ Data are least squares means of 4 observations per treatments.

${ }^{2}$ Basal = basal diet; $\mathrm{PRO}=$ basal diet $+1 \mathrm{~g} / \mathrm{kg}$ probiotics; FRB $=$ basal diet $+10 \mathrm{~g} / \mathrm{kg}$ Lactobacillus-fermented rice bran; FCR $=$ basal diet $+10 \mathrm{~g} / \mathrm{kg}$ Lactobacillus-fermented broken rice.

${ }^{3}$ Pooled standard error of the means.

cholesterol because of the hydrophobic high molecular weight fraction produced by the enzymatic hydrolysis in rats. Xiao et al. (2003) reported that a dietary of milk products fermented by Bifidobacterium longum decreased the concentrations of total cholesterol and LDL-cholesterol in humans. Moreover, lactic acid bacteria have the capacity to assimilate and bind cholesterol (Hosono and Tonooka, 1995) which reduced serum total cholesterol due to inhibited absorption of bile acids in the intestine. Several mechanisms for cholesterol removal by probiotics have been proposed, such as assimilation of cholesterol into bacterial cell membranes (Kimoto et al., 2002), production of short-chain fatty acids (SCFAs) during the growth of probiotics (Trautwein et al., 1998), and cholesterol conversion into coprostanol (Lye et al., 2010). These acids enter the small intestine, where they are absorbed and directed to the liver, and a decrease in bile acid recycling would ultimately result in a lowering of serum cholesterol concentration, because cholesterol is used for bile acid synthesis (StOnge et al., 2000).

Egg yolk cholesterol was less $(P<0.05)$ for FRB and FBR treatment groups than for the basal treatment. Recently, considerable attention has been paid to the potential of feed supplement in altering lipid metabolism. It was reported that supplementation of probiotics or natto in diets reduce choles- 
Table 7. Egg cholesterol of laying hens fed the diet containing probiotics, fermented rice bran and fermented broken rice ${ }^{1}$

\begin{tabular}{|c|c|c|c|c|c|c|}
\hline \multirow{2}{*}{ Items } & \multicolumn{4}{|c|}{ Dietary treatments ${ }^{2}$} & \multirow{2}{*}{$\mathrm{SEM}^{3}$} & \multirow{2}{*}{$p$-value } \\
\hline & Basal & PRO & FRB & FBR & & \\
\hline Egg cholesterol $(\mathrm{mg} / \mathrm{g})$ & $15.94^{\mathrm{a}}$ & $14.94^{\mathrm{ab}}$ & $13.81^{\mathrm{b}}$ & $13.82^{\mathrm{b}}$ & 0.29 & 0.03 \\
\hline \multicolumn{7}{|c|}{,b Values in a row with no common superscripts letter are significantly different $(P<0.05)$. } \\
\hline \multicolumn{7}{|c|}{$\begin{array}{l}\text { Basal = basal diet; PRO = basal diet }+1 \mathrm{~g} / \mathrm{kg} \text { probiotics; FRB }=\text { basal diet }+10 \mathrm{~g} / \mathrm{kg} \text { Lactobacillus-fermented rice bran; FCR }=\text { basal } \\
\text { diet }+10 \mathrm{~g} / \mathrm{kg} \text { Lactobacillus-fermented broken rice. }\end{array}$} \\
\hline
\end{tabular}

terol concentrations in egg yolk in laying hens (Mohan et al., 1995; Haddadin et al., 1996; Fujiwara et al., 2008). Our finding of the reduction in yolk cholesterol agrees with these results. It was also reported that the yolk cholesterol levels were Bareduced by dried Bacillus subtilis culture supplementation (Xu et al., 2006). It is possible that some of the organisms present in the probiotic preparation could assimilate cholesterol present in the gastrointestinal tract for their own cellular metabolism, thus reducing the amount absorbed, as suggested by Gilliland et al. (1985). Kalavathy et al. (2003) indicated that lactic acid bacterial strains are able to alter the enterohepatic cycle and reduce cholesterol through the assimilation of dietary cholesterol into the bacterial cells and the bile salt hydrolate activity in the intestine. Another reason for the decrease of cholesterol in probiotics-fed host, suggested by Fukushima and Nakano (1995), is that HMG-CoA reductase is the rate limiting enzyme for cholesterol synthesis and is regulated via a negative feedback mechanism medicated by sterols and non-sterol metabolites derived from mevalonate, the product of the reaction catalyzed by reductase.

\section{CONCLUSION}

The results of the current experiment indicate that the dietary supplementation of fermented rice bran or fermented half crushed rice improves the laying performance and reduces total cholesterol in the serum and cholesterol in egg yolk of Hy-Line Brwon laying hens. It may be beneficial to supplement the diets of laying hens with fermented rice bran or fermented half crushed in the absence of probiotics.

\section{ACKNOWLEDGEMENTS}

This work carried out with the support of "Cooperative Research Program for Agriculture Science \& Technology Development (Project title: Development of fermented feed using poultry by-product of rice processing, Project No. PJ009475)" Rural Development Administration, Republic of Korea and this study was supported by 2017 the RDA Fellowship Program of, Rural Development Administration, Republic of Korea.

\section{REFERENCES}

Alzawqari M, Moghaddam HN, Kermanshahi H, Raji AR 2011 The effect of desiccated ox bile supplementation on performance, fat digestibility, gut morphology and blood chemistry of broiler chickens fed tallow diets. J Appl Anim Res 39:169-174.

AOAC 1990 Official Method of Analysis. 15 ${ }^{\text {th }}$ ed. Association of Official Analytical Chemists, Washington, DC.

Cao FL, Zhang XH, Yu WW, Zhao LG, Wang T 2012 Effect of feeding fermented Ginko biloba leaves on growth performance, meat quality, and lipid metabolism in broilers. Poult Sci 91:1210-1221.

Chu GM, Yang BS, Kim HY, Kim JH, Ha JH, Kim CH, Lee SD, Song YM 2011 Effects of supplemental fermented agro by-products diet on the growth performances, blood characteristics and carcass traits in fattening pigs. AsianAust J Anim Sci 24:1464-1472.

De Marco M, Peiretti PG, Miragila N, Bergero D 2014 Apparent digestibility of broken rice in horse using in vivo and in vitro methods. Animal 8:245-249.

Dini H 2010 The nutrient evaluation of fermented rice bran as poultry feed. Int J Poult Sci 9:152-154.

Eisen EJ, Bohren BB, McKean HE 1962 The haugh units as 
a measure of egg albumen quality. Poult Sci 41:1461-1468.

Fukushima M, Nakano M 1995 The effect of a probiotic on faecal and liver lipid classes in rats. Br $\mathrm{J}$ Nutr 73:701710 .

Fujiwara K, Miyaguchi Y, Toyoda A, Nakamura Y, Yamazaki M, Nakashima K, Abe H 2008 Effect of fermented soybean "Natto" supplement on egg production and qualities. Asian-Aust J Anim Sci 21:1610-1615.

Ganong WE 1999 Review of Medicinal Physiology. 19 ${ }^{\text {th }}$ ed. Stanford, Conneecticut, Appletonand Lange. p 353.

Gilliland SE, Nelson CR, Maxwell C 1985 Assimilation of cholesterol by Lactobacillus acidophilus bacteria. Appl Environ Microbiol 49:377-381.

Haddadin MS, Abdulrahim SM, Hashlamoun EA, Robinson RK 1996 The effect of Lactobacillus acidophilus on the production and chemical composition oh hen's eggs. Poult Sci 75:491-494.

Hayat Z, Cherian G, Pasha TN, Khattak FM, Jabber MA 2009 Effect of feeding flax and two types of antioxidants on egg production, egg quality, and lipid composition eggs. J Appl Poult Res 18:541-551.

Hosono A, Tonooka T 1995 Binding of cholesterol with lactic acid bacterial cells. Milchwissenschaft 50:556-560.

Huang MK, Choi YJ, Hodue R, Lee JW, Lee B, Zhao X 2004 Effects of Lactobacilli and an acidophilic fungus on the production performance and immune response in broiler chickens. Poult Sci 83:788-795.

Huang TC, Chen CP, Wefler V, Raftery A 1961 A stable reagent for the Libermann-Burchard reaction. Analytical Chem 33:1405-1407.

Johnson TS, Zuk M 1998 Parasites, morphology, and blood characters in male red jungle fowl during development. Condor 100:749-752.

Kalabathy R, Abdullah N, Jalaudin S, Ho YW 2003 Effect of Lactobacillus cultures on growth performance, abdominal fat deposition, serum lipids and weight of organs of broiler chickens. Br Poult Sci 44:139-144.

Kang HK, Kim JH, Kim CH 2015 Effect of dietary supplementation with fermented rice bran on the growth performance, blood parameters and intestinal microflora of broiler chickens. Europ Poultry Sci 79. DOI: 10.1399/eps.2015.112

Kim CH, Kim GB, Chang MB, Bae GS, Paik IK, Kil DY
2012 Effect of dietary supplementation of Lactobacillusfermented Artemisia princeps on growth performance, meat lipid peroxidation, and intestinal microflora in Hy-Line Brown male chickens. Poult Sci 91:2845-2851.

Kim HY, Song YM, Kang YS, Kim CH, Lee SD, Chowdappa R, Ha JH, Kang, SM 2006 The effect of fermented persimmon shell diet supplementation on the growth performance and blood parameters in finishing pigs. Anim Sci J 77:314-319.

Kimoto H, Ohmomo S, Okamoto T 2002 Cholesterol removal from media by Lactococci. J Dairy Sci 85:3182-3188.

Kitawaki R, Nishimura Y, Takagi N, Iwaaki M, Tsuzuki K, Fukuda M 2009 Effects of Lactobacillus fermented soymilk and soy yogurt on hepatic lipid accumulation in rats fed a cholesterol-free diet. Biosci Biotechnol Biochem 73: 1484-1488.

Kratzer FH, Earl L, Chiaravanont C 1974 Factors influencing the feeding value of rice bran for chickens. Poult Sci 53: 1795-1800.

Kubad RC, Singh K, Saxena K, Eriksson K 1997 Microorganism as alternative source protein. Nutrition Rev 55:65-75.

Lee YL, Yang JH, Mau JL 2008 Antioxidant properties water extracts form Monascus fermented soybeans. Food Chem 106:1128-1137.

Lucas AM, Jamroz C 1961 Atlas of Avian Hematology. USDA Monograph 25. USDA, Wasington DC.

Lye HS, Rusul G, Liong MT 2010 Removal of cholesterol by Lactobacilli via incorporation and conversion to coprostanol. J Dairy Sci 93:1383-1392.

Masoudi A, Chagi M, Bojarpour M, Mirzadeh, K 2011 Effects of different levels of date pits on performance, carcass characteristics and blood parameters of broiler chickens. J Appl Poult Res 39:399-405.

Maust LM, Scolt ML, Pond WC 1972 The metabolizable energy of rice bran, cassva flour and blackeye cowpeas for growing chickens. Poult Sci 51:1397-1401.

Mohan B, Kadirvel R, Bhaskaran M, Natatajan A 1995 Effect of probiotic supplementation on serum/yolk cholesterol and on eggshell thickness in layers. Br Poult Sci 36:799-803.

Mu KS, Kasim AB, Ideris A, Saad CR 2011 Effect of fermented rice bran, bio-converted byproduct on performance of broiler chickens. J Anim Vet Adv 10:2990-2995. 
NRC 1994 Nutrient Requirements of Poultry, $9^{\text {th }}$ Revedn. National Acadaemy Press, Washington, DC.

Ott RL, Longnecker MT 2009 An Introduction to Statistical Method and Data Analysis. Belmont, Cal Duxbury.

Panda AK, Rama RSV, Raju MVLN 2006 Sharma SR. Dietary supplementation of Lactobacillus sporogenes on performance and serum biochemico-lipid profile of broiler chickens. J Poult Sci 43:235-240.

Rezaei M 2006 Utilization of mixed rice bran in laying hen diets. Pakistan J Biol Sci 9:1420-1423.

Ryan EP, Heuberger AL, Weir TL, Barnett B, Broeckling CD, Prenni JE 2011 Rice bran fermented with Saccharomyces boulardii generates novel metabolite profiles with bioactivity. J Agri Food Chem 59:1862-1870.

Saunders RM 1985 Rice bran: Composition and potential food uses. Food Rev Int 1:465-495.

St-Onge MP, Farnworth ER, Jones PJH 2000 Consumption of fermented and nonfermented dairy products: Effects on cholesterol concentrations and metabolism. Am J Clinical Nutr 71:674-681.

Steel RGD, Torrie JH, Dickey DA 1997 Principles and Procedures of Statistics: A Biochemical Approach $3^{\text {rd }}$ ed. McGraw Hill Book Co., New York, NY.

Supriyati T, Haryati T, Susanti T, Susana IWR 2015 Nutritional value rice bran fermented by Bacillus amyloliquefaciens and humic substance and its utilization as a feed ingredient for broiler chickens. Asian-Aust J Anim Sci 28:231-238.

Trautwein EA, Rieckhoff D, Erbersdobler HF 1998 Dietary inulin lowers plasma cholesterol and triacylglycerol and alters biliary bile acid profile in hamsters. J Nutr 128:1937-
1943.

Van Dalen G 2004 Determination of the size distribution and percentage of broken kernels of rice using flatbed scanning and image analysis. Food Res Int 37:51-58.

Wang CY, Lin HT, Wu SC 2011 Influence of dietary supplementation with Bacillus-fermented adlay on lipid metabolism, antioxidant status and intestinal microflora in hamsters. J Sci Food Agriculture 91:2271-2276.

Wagner RD, Pierson C, Warner T, Dohnalek M, Hilty M, Balish E 2000 Probiotic effects of feeding heat killed Lactobacillus acidophilus and Lactobacillus casei to Candida albicans-colonized immunodeficient mice. J Food Protect 63:638-644.

Warren BE, Farrell DJ 1990 The nutritive value of full-fat Australian rice bran. I. Chemical composition. Anim Feed Sci Technol 27:219-228.

Xiao JZ, Kondo S, Takahashi N, Miyaji K, Oshida K, Hiramatsu A, Iwatsuki K, Kokubo S, Hosono A 2003 Effects of milk products fermented Bifiobacterium longum on blood lipids in rats and healthy adult male volunteers. J Dairy Sci 86:2452-2461.

Xu CL, Ji CJ, Ma Q, Hao K, Jin ZY, Li K 2006 Effects of a dried Bacillus subtilis culture on egg quality. Poult Sci 85:364-368.

Zombade SS, Lodh GN, Ichhponani JS 1982 Evaluation of nutrient composition in raw and parboiled rice bran. J Anim Sci 52:573-575.

Received Sep. 12, 2017, Revised Dec. 7, 2017, Accepted Dec.

8, 2017 
